\title{
PENGARUH TERAPI MUROTTAL AL-QUR'AN TERHADAP PENURUNAN SKALA NYERI PADA PASIEN CEDERA KEPALA DI RUANG BEDAH UMUM RSUD ULIN BANJARMASIN
}

\author{
Noor Khalilati ${ }^{1)}$ dan Muhammad Humaidi ${ }^{1)}$ \\ ${ }^{1}$ Fakultas Keperawatan dan Ilmu Kesehatan Universitas Muhammadiyah Banjarmasin \\ Email : noor.khalilati@yahoo.co.id
}

\begin{abstract}
Head injury is one of the main causes of death and disability, so far pharmacologic treatment is used to treat the pain. The researcher tried to provide treatment with listening to murottal Al-Qur'an therapy so that was able to reduce pain due to head injury. The aim was to determine the effect of listening to murottal AlQur'an therapy on the reduction in pain scale of head injury patients in the operating room of Ulin Hospital of Banjarmasin. The design was Quasy_Experimental with One Group Pretest-Postest. The population were all patients of head injury in operating room and the sampling technique used purposive sampling. The instrument used a questionnaire sheet. The measurement of the Numerical Rating Scale (NRS) used univariate analysis and bivariate analysis with the Paired T-Test. The level of moderate pain scale before listening mostly amounted to $15(100 \%)$ people, after doing therapy there were $13(86.7 \%)$ people with mild pain. There was an influence of listening to murottal Al-Qur'an on the reduction of the pain scale of head injury patients in operating room. The hypothesis is accepted at the significance level of $0.000<0.05$. The results of this paper are expected to provide information to patients in reducing pain's response.
\end{abstract}

Keyword: Head Injury Patient, Murottal Al-Qur'an, Pain Scale

\section{PENDAHULUAN}

Perkembangan zaman dan peningkatan teknologi sekarang semakin pesat berkembang diseluruh dunia, pengeluaran berbagai macam alat transportasi darat baik kendaraan roda dua ataupun kendaraan roda empat. Demikian juga dengan peningkatan kinerja oleh tenaga kerja Pabrik industri yang harus diperhatikan Kesehatan dan Keselamatan Kerja. Keadaan ini sangat mungkin untuk terjadinya kecelakaan lalu lintas maupun kecelakaan kerja. khususnya parapengguna alat transportasi maupun para karyawan Pabrik. Trauma yang terjadi pada saat kecelakaan lalu lintas maupun kerja di antaranya adalah trauma kepala atau lebih sering disebut cedera kepala.

Menurut WHO (World Health Organization) handicap International, yang sudah mengunjungi Bir Hospital, Tribhuvan University Teaching Hospital, Patan Hospital, dan Bhaktapur Hospital, satu dari enam orang yang mengalami cedera diantaranya adalah usia 6-8 tahun, dengan prevalensi yang sama untuk usia diatas 60 tahun. 1 dari 60 yang mengalami cedera adalah orang yang berusia dibawah 2 tahun. Sebagian besar dari orang yang mengalami cedera tersebut adalah berusia 19-60 tahun. 6\% dari cedera meliputi cedera tulang belakang, $11 \%$ cedera kepala, dan $13 \%$ dari kasus tersebut adalah cedera sum - sum tulang belakang (Nepal, 2015).

Berdasarkan hasil Riset Kesehatan Dasar (RISKESDAS) tahun 2013, jumlah data yang dianalisis seluruhnya 1.027 .758 orang untuk semua umur. Adapun responden yang pernah mengalami cedera 84.774 orang dan tidak cedera 942.984 orang. Prevalensi cedera secara nasional adalah $8,2 \%$ dan prevalensi angka cedera kepala di Sulawesi utara sebesar 8,3\%. Prevalensi cedera tertinggi berdasarkan karakteristik responden yaitu pada kelompok umur 15-24 tahun (11,7\%), dan pada lakilaki (10,1\%), Pada tahun 2013 terdapat peningkatan prevalensi cedera menjadi $8,2 \%$, dengan urutan penyebab cedera terbanyak adalah jatuh 40,9\%, kecelakaan sepeda motor $(40,6 \%)$, cedera karena benda tajam/tumpul 7,3\%, transportasi darat lainnya 
7,1\% dan kejatuhan 2,5\% (Badan Penelitian dan Pengembangan Kesehatan Departemen Kesehatan Republik Indonesia, 2013).

Prevalensi cedera kepala di Provensi Kalimantan Selatan yang terbesar terdapat di Kabupaten Kota Banjarmasin, Banjar, dan Hulu Sungai Selatan. Prevalensi penyebab kejadian cedera kepala yang tertinggi adalah jatuh $(61,2 \%)$, akibat terkena benda tajam/ tumpul (23,6\%), dan kecelakaan transportasi di darat (17,9\%) (Soendoro, 2015).

Berdasarkan data yang di dapat dari rekam medik di ruang bedah umun Rumah Sakit Umum Ulin Bajarmasin, kasus cedera kepala dari bulan Januari 2017 sampai Agustus 2018 didapatkan data pasien cedera kepala yang di tangani di Rumah Sakit Umum Ulin Banjarmasin berjumlah157 kasus, pada tahun 2017 dari CKR dan CKS sebanyak 151, kasus CKB 6 kasus, pada tahun 2018 dari CKR dan CKS Bulan Januari sampai Agustus sebanyak 103 kasus, dan CKB 1 kasus.

Trauma kepala merupakan kejadian yang sangat sering dijumpai. Lebih dari $50 \%$ penderita trauma adalah penderita trauma kepala, bila multi trauma (cedera lebih dari satu bagian tubuh) maka $50 \%$ penderita tersebut karena trauma kepala. Trauma kepala merupakan keadaan yang serius, oleh karena itu pemberi pertolongan pertama kali yang melihat penderita tersebut diharapkan mempunyai pengetahuan praktis untuk melakukan pertolongan pertama penderita, sebelum melakukan rujukan kepada rumah sakit yang mempunyai fasilitas bedah saraf.

Tindakan pemberian oksigen yang adekuat dan mempertahankan tekanan darah yang cukup untuk perfusi otak dan menghindarkan terjadi cidera otak sekunder merupakan pokok-pokok tindakan yang sangat penting untuk keberhasilan kesembuhan penderita. Ahli bedah saraf harus dilibatkan seawak mungkin, terutama bila penderita mengalami koma atau dicurigai menderita lesi intrakranial (Wartatmo et al, 2017: 54).

Cedera kepala merupakan salah satu penyebab kematian dan kecacatan utama pada kelompok usia produktif dan sebagian besar terjadi akibat kecelakaan lalu lintas, penilaian dan tindakan awal di ruang gawat darurat sangat menentukan penatalaksanaan dan prognosis selanjutnya (Tobing, 2011).
Selain tatalaksana medis pada pasien cedera kepalakeluhan utama yang biasa dikeluhkan adalah nyeri. Apabila pasien mengeluh nyeri maka hanya satu tindakan yang mereka inginkan yaitu mengurangi rasa nyeri tersebut, untuk mengurangi rasa nyeri tersebut maka harus dilakukan manajemen nyeri yang benar-benar berpengaruh, manajemen nyeri mempunyai beberapa tindakan atau prosedur baik secara farmakologis maupun non farmakologis.

Adapun tindakan untuk mengatasi nyeri pada cedera kepala dapat dibedakan dalam dua kelompok utama,yaitu tindakan pengobatan (farmakologi) dan tindakan non farmakologi (tanpa pengobatan). Metode penatalaksanaan non far-makologis tindakan distraksi dilakukan dengan mengalihkan perhatian pasien dari rasa nyeri.Teknik distraksi yang dapat dilakukan antara lain: bernapas dengan lambat dan berirama secara teratur, menyanyi berirama dan menghitung ketukannya, mendengarkan musik, mendengarkan murottal Al-Qur'an dan massage (pijatan).

Berdasarkan latar belakang tersebut maka peneliti tertarik untuk melakukan penelitian terkait tentang Pengaruh Terapi Murottal Al-Qur'an Terhadap Penurunan Skala Nyeri Pada Pasien Cedera Kepala di RuangBedah umum RSUD Ulin Banjarmasin.

\section{METODE PENELITIAN}

Penelitian ini adalah penelitian quasy eksperimen dengan metode one group pre-test posttest design ini menggunakan satu kelompok subjek, pengukuran dilakukan sebelum dan sesudah perlakuan. Perbedaan kedua hasil pengukuran dianggap sebagai efek perlakuan (Saryono, 2011). Design penelitian ini peneliti melakukan penilaian nyeri pada kelompok intervensi sebelum dan sesudah dilakukan murottal Al-Qur'an.Penelitian ini dilaksanakan di ruang bedah umum RSUD Ulin Banjarmasin pada tanggal 30 Januari - 30 September 2019. Populasi pada penelitian ini adalah semua pasien yang mengalami cedera kepala di ruang bedah umum RSUD Ulin Banjarmasin. Sampel dalam penelitian ini sebanyak 20 orang responden yang memenuhi kriteria inklusi dan ekslusi. Sampel penelitian ini diambil menngunakan teknik purposive sampling, teknik purposive sampling adalah didasarkan pada suatu pertimbangan tertentu yang dibuat oleh peneliti berdasarkan atas ciri atau 
sifat-sifat populasi yang sudah diketahui sebelumnya (Notoatmodjo, 2014). Agar karakteristik sampel tidak menyimpang dari populasinya, maka sebelum dilakukan pengambilan sampel perlu ditentukan kriteria inklusi dan eklusi. Kriteria inklusi yaitu ciriciri yang perlu dipenuhi setiap anggota populasi yang dapat diambil sebagai sampel. Kriteria eklusi yaitu ciri-ciri anggota populasi yang tidak dapat diambil sebagai sampel (Notoatmodjo, 2014). Kriteria inklusi dan eklusi pada penelitian ini yaitu:

a. Kriteria Inklusi

Kriteria Inklusi adalah kriteria atau syarat responden yang dijadikan sampel. Kriteria inklusi antara lain:

a. Pasien yang bersedia menjadi responden penelitian.

b. Responden merupakan pasien di ruang Bedah umum RSUD Ulin Banjarmasin.

c. Responden yang beragama islam

d. Responden yang terdiagnosa cedera kepala dan mengalami nyeri akut dengan skala nyeri ringan dan sedang.

e. Responden memiliki kemampuan kognitif yang mampu memahami instruksi pertanyaan peneliti.

f. Responden yang mengalami nyeri berulang sebelum pemberian terapi farmakologi selanjutnya.

g. Bersedia menjadi responden

b. Kriteria Ekslusi

Kriteria Ekslusi adalah kriteria atau syarat responden yang tidak dijadikan sampel :

a. Responden yang tidak bersedian dilakukan penelitian

b. Responden tiba-tiba mengalami kegawatan mengancam nyawa.

c. Responden anak dan remaja awal usia 0-16 tahun.

Pengukuran skala nyeri menggunakan numeric rating scale(NRS) yang dilakukan sebelum dan sesudah diberikan tindakan terapi mendengarkan murottal Al-Qur'an. Skala numerik digunakan sebagai pengganti alat pendeskrisian kata. Dalam hal ini pasien menilai nyeri dengan skala 0 sampai 10 dengan 0 (tidak ada nyeri). 1-3 ( nyeri ringan), 4-6 (nyeri sedang), 7-10 (nyeri berat)
Data dianalisa secara 2 tahap yaitu : analisa bivariat untuk melihatdistribusi frekuensi dan analisa univariat untuk mengetahui skala nyeri sebelum dan sesudah dilakukan pemberian terapi mendengarkan murottal Al-Qur'an.

\section{HASIL DAN PEMBAHASAN}

Tingkat skala nyeri sebelum dilakukan terapi mendengarkan murotal Al-Qur'an pada pasien cedera kepala di ruang Bedah RSUD Ulin Banjarmasin.

Hasil yang didapat sebelum dilakukan terapi mendengarkan murottal Al-Qur'an menunjukkan bahwa responden mengalami tingkat skala nyeri ringan berjumlah 5 orang $(15 \%)$ dan yang mengalami nyeri sedang berjumlah 15 orang $(75 \%)$ dari data keseluruhan responden berjumlah 20 (100\%) orang (Tabel 1).

Tabel 1. Distribusi frekuensi berdasarkan tingkat skala nyeri sebelum dilakukan terapi mendengarkan murotal Al-Qur'an pada pasien cedera kepala di ruang Bedah RSUD Ulin Banjarmasin

\begin{tabular}{llcc}
\hline No & Tingkat skala nyeri & F & \% \\
\hline 1. & Tidak ada nyeri & 0 & 0 \\
2. & Nyeri ringan & 5 & 25 \\
3. & Nyeri sedang & 15 & 75 \\
4. & Nyeri berat & 0 & 0 \\
\hline & Jumlah & 20 & 100 \\
\hline
\end{tabular}

Hasil penelitian ini sesuai dengan teori Wahyuningsih (2014) yang menyatakan bahwa nyeri merupakan pengalaman yang bersifat subjektif atau tidak dapat dirasakan oleh orang lain. Nyeri dapat disebabkan oleh berbagai stimulus seperti mekanik, termal, kimia, atau elektrik pada ujung-ujung saraf. Perawat dapat mengetahui adanya nyeri dari keluhan pasien dan tanda umum atau respon fisiologis tubuh pasien terhadap nyeri. Sewaktu nyeri biasanya pasien akan tampak meringis, kesakitan, nadi meningkat, berkeringat, napas lebih cepat, pucat, berteriak, menangis, dan tekanan darah meningkat.

Nyeri juga diartikan sebagai suatu kondisi yang membuat seseorang menderita secara fisik dan mental atau perasaan yang dapat menimbulkan ketegangan (Hidayat, 2012). Selain itu menurut Potter \& perry (2010) teknik koping mempengaruhi 
kemampuan dalam mengatasi nyeri. Hal ini sering terjadi karena klien merasa kehilangan kontrol terhadap lingkungan atau terhadap hasil akhir dari suatu peristiwa yang terjadi. Dengan demikian, gaya koping mempengaruhi kemampuan individu tersebut untuk mengatasi nyeri. Seseorang yang belum pernah mendapatkan teknik koping yang baik tentu respon nyerinya buruk

Respon tubuh terhadap nyeri akan membangkitkan reaksi fight or flight dengan merangsang sistem saraf simpatis, sedangkan pada kategori nyeri berat, tidak dapat ditahan dan nyeri pada organ tubuh bagian dalam, akan merangsang saraf parasimpatis. Respon fisik mencakup takikardi, takipnea, meningkatnya aliran darah perifer, meningkatnya tekanan darah dan keluarnya katekolamin (Budi, 2012; Khodijah, 2011).

Tingkat skala nyeri setelah dilakukan terapi mendengarkan murottal Al-Qur'an pada pasien cedera kepala di ruang Bedah RSUD Ulin Banjarmasin

Setelah dilakukan terapi mendengarkan murottal Al-Qur'an terdapat adanya perubahan terhadap respon rasa nyeri sedang menjadi ringan berjumlah 18 orang $(90 \%)$ responden, dan 2 orang (10\%) responden yang mengalami nyeri sedang (Tabel 2).

Tabel 2. Distribusi frekuensi berdasarkan tingkat skala nyeri setelah dilakukan terapi mendengarkan murottal Al-Qur'an pada pasien cedera kepala di ruang Bedah RSUD Ulin Banjarmasin

\begin{tabular}{llrr}
\hline No & Tingkat skalanyeri & F & \% \\
\hline 1. & Tidak ada nyeri & 0 & 0 \\
2. & Nyeri ringan & 18 & 90 \\
3. & Nyeri sedang & 2 & 10 \\
4. & Nyeri berat & 0 & 0 \\
\hline & Jumlah & 20 & 100 \\
\hline
\end{tabular}

Hasil penelitian ini sejalan dengan penelitianWiji (2016) bahwa Setelah diberikan distraksi audio: murottal Al-Qur'an dari 31 responden 23 orang $(74,2 \%)$ mengalami nyeri ringan, dan 8 orang $(25.8 \%)$ mengalami nyeri sedang. Salah satu metode yang sering digunakan untuk mengurangi atau mengatasi nyeri adalah distraksi. Distraksi merupakan pengalihan dari focus perhatian terhadap nyeri ke stimulus yang lain. Teknik distraksi bekerja memberi pengaruh paling baik untuk jangka waktu yang singkat, serta untuk mengatasi nyeri intensif yang hanya berlangsung beberapa menit. Salah satu teknik distraksi yang efektif adalah terapi murottal (mendengarkan bacaan ayat-ayat suci Al-Qur'an), yang dapat menurunkan nyeri fisiologis, stres, dan kecemasan dengan mengalihkan perhatian seseorang dari nyeri (Mulyani, 2016).

Distraksi audio: murottal Al-Qur'an adalah distraksi audio dengan mendengarkan ayat-ayat suci Al-Qur'an. Al-Qur'an memberikan manfaat dan obat yang mujarab bagi seseorang yang mengalami kegundahan hati, keputusasaan, dan kecemasan. AlQur'an memberikan ketenangan kepada sistem dan unsur tubuh manusia. Murottal Al-Qur'an merupakan bacaan Al-Qur'an yang dibacakan oleh Qori' atau Qori'ah sesuai dengan tartil dan tajwid yang mengalun indah yang dikemas dalam media audio seperti kaset, $\mathrm{CD}$ atau data digital.

Lantunan Al-Qur'an secara fisik mengandung unsur suara manusia, suara manusia merupakan instrument penyembuhan yang menakjubkan dan alat yang paling mudah dijangkau. Suara dapat menurunkan hormon-hormon stres, mengaktifkan hormon endorfin alami, meningkatkan perasaan rileks, dan mengalihkan perhatian dari rasa takut, cemas, dan tegang, memperbaiki sistem kimia tubuh sehingga menurunkan tekanan darah serta memperlambat pernafasan, detak jantung, denyut nadi, dan aktivitas gelombang otak (Mulyani, 2016)

Salah satu teknik distraksi yang efektif adalah terapi murottal (mendengarkan bacaan ayat-ayat suci Al-Qur'an), yang dapat menurunkan nyeri fisiologis, stres, dan kecemasan dengan mengalihkan perhatian seseorang dari nyeri. Sehingga setelah dilakukan pengalihan perhatian melalui metode mendengarkan suara alunan ayat suci Al-Qur'an dapat memberikan rasa nyaman sehingga responden tidak berfokus terhadap rasa nyeri.

\section{Analisa pengaruh mendegarkan terapi murottal Al-Qur'an terhadap penurunan skala nyeri pada pasien cedera kepala.}

Hasil penelitian ini disimpulkan bahwa ada pengaruh perbedaan setelah diberikan terapi mendengarkan murottal Al-Qur'an. Berdasarkan 
Tabel 3 didapatkan hasil uji statistik Paired T-Test nilai pvalue $=0,000 \leq \alpha=0,05$, artinya ada pengaruh mendengarkan murottal Al-Qur'an terhadap penurunan skala nyeri pada pasien cedera kepala di ruang bedah umum RSUD Ulin Banjarmasin.

Tabel 3. Perbedaan Sebelum dan Sesudah Dilakukan Terapi Mendengarkan Murottal Al-Qur'an Terhadap Penurunan Skala Nyeri Pada Pasien Cedera Kepala di Ruang Bedah Umum RSUD Ulin Banjarmasin

\begin{tabular}{|c|c|c|c|c|c|}
\hline $\begin{array}{l}\text { Perlakuan } \\
\text { terapi } \\
\text { Murottal } \\
\text { AL-Qur'an } \\
\end{array}$ & $\begin{array}{l}\text { Mean } \\
\left({ }^{\circ} \mathrm{C}\right)\end{array}$ & SD & $\mathbf{N}$ & S.E & $\begin{array}{l}\text { Uji } \\
\text { Paired } \\
\text { T-Test } \\
\text { Pvalue }\end{array}$ \\
\hline $\begin{array}{l}\text { Sebelum } \\
\text { (Pretest) } \\
\text { Perlakuan }\end{array}$ & 4,60 & 1,35 & 20 & 0,302 & $\mathbf{0 , 0 0 0}$ \\
\hline $\begin{array}{l}\text { Sesudah } \\
\text { (Posttest) } \\
\text { Perlakuan }\end{array}$ & 2,25 & 0,96 & 20 & 0,216 & \\
\hline
\end{tabular}

Meskipun pada 2 orang responden yang masih dalam kategori skala nyeri sedang sebelum dan sesudah dilakukan terapi, akan tetapi pada hasil skala nyeri (NRS) yang di dapat mengalami perubahan ataupun penurunan. Total keseluruhan jumlah responden yang dilakukan terapi mendengarkan murottal Al-Qur'an berjumlah 20 $(100 \%)$. Hasil penelitian ini sejalan dengan penelitian Wiji (2016) bahwa Ada pengaruh dan perbedaan setelah diberikan distraksi audio: murottal Al-Qur'an dengan nilai $\mathrm{p}<0.05$ dan $\mathrm{p}=0.000$ pada signifikasi 95\%. Terapi berupa murrotal Al Qur'an dapat meningkatkan stimulus dan efek relaksasi serta ketenangan dalam diri sehingga dapat mempengaruhi persepsi, informasi serta emosi dalam diri yang berdampak kepada kemampuan berupa adaptasi kognitif yang mampu mengontrol rasa nyeri hingga pada batas yang dapat ditoleransi (Handayani dkk, 2014).

Terapi murottal memberikan dampak psikologis ke arah positif, hal ini dikarenakan ketika murottal diperdengarkan dan sampai ke otak, maka murottal ini akan diterjemahkan oleh otak. Persepsi kita ditentukan oleh semua yang telah terakumulasi, keinginan hasrat, kebutuhan dan pra anggapan. Dengan terapi murottal maka kualitas kesadaran seseorang terhadap Tuhan akan meningkat, baik orang tersebut tahu arti $\mathrm{Al}$-qur'an atau tidak.
Kesadaran ini akan menyebabkan totalitas kepasrahan kepada Allah SWT, dalam keadaan ini otak berada pada gelombang pada frekuensi 7-14 $\mathrm{Hz}$, ini merupakan keadaan energi otak yang optimal dan dapat menyingkirkan stres dan menurunkan kecemasan (Zahrofi, 2013). Organ tubuh yang dapat membantu dalam proses distraksi atau pengalihan perhatian melalui pendengaran ialah telinga. Telinga adalah salah satu perangkat tubuh yang paling kompleks. Para peneliti menegaskan bahwa indra pendengaran ini sangat penting bagi keseimbangan seluruh tubuh.

Ketika indra ini mengalami gangguan maka sebagian besar perangkat tubuh terpengaruh dan mengalami ketidakseimbangan juga. Karena itu cara paling baik menjaga perangkat tubuh adalah dengan menggunakan pengaruh suara. Suara itu akan direspon oleh sel-sel tubuh, lalu memperbaiki kerjanya dan mengembalikan keseimbangan (Alkaheel, 2012).

Jika kita menganalisis suara Al-Qur'an maka dia menunjukan getaran suara atau gelombang yang sampai kepada kita gelombang-gelombang suara ini bergerak ke telinga, lalu masuk kedalam otak (tentu setelah terlebih dahulu mengalami perubahan dalam gendang telinga menjadi getaran-getaran atau isyarat-isyarat elektronik). Lalu, gelombang suara ini mempengaruhi daerah-daerah tertentu dalam otak, dimana mereka kemudian memberikan perintah kepada tubuh untuk merespon suara tersebut (Alkaheel, 2012).

Pengaruh terapi mendengarkanayat-ayat AlQur'an berupa, adanya perubahan perubahan arus listrik di otot, perubahan sirkulasi darah,perubahan detak jantung dan kadar darah pada kulit. Perubahan tersebut menunjukan adanya relaksasi atau penurunan ketegangan urat saraf reflektif yang mengakibatkan terjadinya pelonggaran pembuluh nadi dan penambahan kadar darah dalam kulit, diiringi dengan penurunan frekuensi detak jantung.

Terapi murotal bekerja pada otak, dimana ketika didorong oleh rangsangan dari luar (terapi AlQur'an), maka otak maka memproduksi zat kimia yang disebut neuropeptide. Molekul ini akan menangkutkan kedalam reseptor -reseptor mereka yang ada di dalam tubuh dan akan memberikan umpan balik berupa kenikmatan atau kenyamanan (Zahrofi, 2013). 
Terapi mendengarkan murottal Al-Qur'an memiliki pengaruh terhadap penurunan rasa nyeri di karenakan kemampuan berupa adaptasi kognitif yang mampu mengontrol rasa nyeri hingga pada batas yang dapat ditoleransi. Al-Qur'an memberikan pengaruh positif bagi psikologis yang mana kesadaran seseorang terhadap Tuhan akan meningkat, kepasrahan dengan ketentuan Allah baik orang tersebut tahu arti $\mathrm{Al}$ quran ataupun tidak.

\section{KESIMPULAN DAN SARAN}

\section{Kesimpulan}

1. Sebelum dilakukan terapi mendengarkan murottal Al-Qur'an sebagian besar responden mengalami tingkat skala nyeri sedangsebanyak 15 orang $(75 \%)$.

2. Setelah dilakukan terapi mendengarkan murottal Al-Qur'an didapatkan jumlah responden yang mengalami tingkat skala nyeri ringan yaitu sebanyak 18 orang $(90 \%)$.

3. Hasil analisis pada penelitian ini ialah adanya perubahan tingkat skala nyeri setelah dilakukan terapi mendengarkan murotal al-qur'an pada pasien cedera kepala di ruang bedah RSUD Ulin Banjarmasin.

\section{Saran}

1. Bagi Responden

Meningkatkan kesadaran masyarakat terutama bagi responden yang mempunyai anggota keluarga tentang pentingnya Terapi bacaan Alqur'an dapat direkomendasikan sebagai terapi komplementer untuk menurunkan nyeri pilihan dan non farmakologiadjuvan dalam menurunkan nyeri pasien.

2. Bagi Profesi Keperawatan

Sebagai bahan informasi dan evaluasi untuk meningkatkan kemampuan dalam memberikan penatalaksanaan yang lebih optimal dan adekuat pada pasien cidera kepala di ruang Bedah RSUD Ulin Banjarmasin.

3. BagiPeneliti

Sebagai pengalaman dan tambahan ilmu pengetahuan mengenai pengaruh murotal AlQur'an terhadap penurunan skala nyeri pada pasien cidera kepala dan bisa menerapkan ilmu yang telah didapatkan selama ini.
Sebagai data dasar bagi mahasiswa/i program studi pendidikan keperawatan Universitas Muhammadiyah Banjarmasin dalam kegiatan yang sama.

\section{DAFTAR PUSTAKA}

Badan Penelitian dan Pengembangan Kesehatan Kementrian Kesehatan RI. 2013. Riset Kesehatan Dasar 2013. http://www.depkes. go.id/resources/download/general/Hasil\%20R iskesdas\%202013.pdf (DiaksesTanggal 01 juni 2018).

Budi, S. M. 2012. Pengaruh Penggunaan Permainan Elektronik Terhadap Nyeri Saat Prosedur Perawatan Luka pada Pasien Bedah ORIF di RSUD Purbalingga (Internet), tersedia dalam <www.lib.ui.ac.id> (diakses tanggal 14 September 2017).

Handayani et al. 2014. Pengaruh Terapi murottal Al-Qur'an Untuk Penurunan Nyeri Persalinan Dan Kecemasan Pada Ibu Bersalin Kala I FaseAktif, Vol.5(2):1-15.

Hidayat. A. A. A. 2010. Metode Penelitian Keperawatan dan Teknik Penulisan Ilmiah, Edisi 2, Jakarta: Salemba Medika.

Nepal. 2015. Health Cluster Bulletin (Internet), May 2015. Available from: www.who.int/en/ (Accessed 12 May 2017).

Notoatmodjo. 2014. Metodologi penelitian kesehatan. Jakarta: PT Rineka Cipta.

Potter, Perry. 2010. Fundamental of Nursing: Concept, Process, and Practice. Edisi 7. Vol. 3. Jakarta: EGC.

Saryono. 2011. Metodologi Penelitian Kesehatan. Yogyakarta: MitraCendika Offset.

Tobing, HG. 2011. Prinsip Ilmu Bedah Saraf, Sagung Seto, Jakarta.

Wahyuningsih, M. 2014. Efektifitas Aroma Terapi Lavender dan Massage Effleurage terhadap Tingkat Nyeri Persalinan Kala I Fase Aktif pada Primigravida di BPS Utami dan Ruang Ponek RSUD Karanganyar (Internet), tersedia dalam <http://digilib.stikeskusumahusada. ac.id/files/ disk1/11/01-gdl-marniwahyu-547-

4. Bagi Institusi Pendidikan

Pengaruh Terapi Murottal Al-Qur'an Terhadap Penurunan Skala Nyeri pada Pasien Cedera Kepala di Ruang Bedah Umum RSUD Ulin Banjarmasin (Noor Khalilati dan Muhammad Humaidi) 
1-skripsi-i.pdf> (diakses tanggal 01

September 2017).

Wartatmo, Het al. 2017. Penanggulangan Penderita Gawat Darurat. Yogyakarta: Pusbankes.

Wiji et al. 2016. Pengaruh Distraksi Audio: Murottal Al-Qur'an Terhadap Penurunan Nyeri Pasien Post Operasi Sectio Caesarea, Skripsi, Sekolah Tinggi Ilmu Kesehatan Muammadiyah Gombong.

Zahrofi, DB. 2013. Pengaruh Pemberian Terapi Murotal Al Qur'an terhadap Tingkat Kecemasan pada Pasien Hemodialisa di RS $P K U$ Muhammadiyah Surakarta. Naskah Publikasi Fakultas Ilmu Kesehatan Universitas Muhammadiyah Surakarta. 